\title{
Performance of Heat Tolerant Clones of Potato in Tropical Coastal Region of India
}

\author{
S. Sunitha ${ }^{1 *}$, V.K. Gupta ${ }^{2}$, Shirly Raichal Anil ${ }^{1}$ and J. Suresh Kumar ${ }^{1}$ \\ ${ }^{1}$ ICAR-Central Tuber Crops Research Institute, Thiruvananthapuram, Kerala, India \\ ${ }^{2}$ ICAR-CPRI, Regional Station, Modipuram, Meerut-250001, UP, India \\ *Corresponding author
}

\begin{abstract}
A B S T R A C T
Keywords

Potato, Heat tolerance, Tropical potato, Marketable tuber yield, Sensory evaluation

\section{Article Info}

Accepted:

24 July 2020

Available Online:

10 August 2020

Potato is a cool weather crop, with temperature being the main limiting factor on production; however it grows under a diverse range of climatic conditions. The vegetative growth of the plant is best at a temperature of $24^{\circ} \mathrm{C}$ while tuber development is favoured at $18^{\circ} \mathrm{C}$. Hence, potato is grown as a summer crop in the hills and as a winter crop in the tropical and subtropical regions. To extend this crop in tropical regions of our country heat tolerant advanced clones of promising crosses developed at ICAR-CPRI, were evaluated/screened during 2016-17 in tropical coastal soils at ICAR-CTCRI, Thiruvananthapuram, Kerala, India. Five advanced hybrids and two released heat tolerant varieties from ICAR-CPRI were evaluated at ICAR-CTCRI, during 2016-17 in Rabi planting season. Higher total tuber yield was obtained in the advanced hybrids HT/7$1329\left(28\right.$ tha $\left.^{-1}\right), \mathrm{HT} / 10-2002\left(25\right.$ tha $\left.^{-1}\right)$ as compared to heat tolerant variety Kufri Surya (20 tha $\left.^{-1}\right)$. Selected genotypes had acceptable texture and taste without bitterness due to alkaloids in organoleptic test conducted after harvest. The taste and crispiness of fried chips was also good for HT/10-2002 followed by HT/7-1329, compared to Kufri Surya.
\end{abstract}

\section{Introduction}

Potao (Solanum tuberosum L.) holds the position of fourth most consumed food crop globally after rice, wheat and maize. This is the most important starch rich crop cultivated in more than 2/3rd countries from the temperate to sub tropics and is a rich source of low fat carbohydrates. Potatoes are often the main source of income and food security in developing countries. It is one of the basic crops which significantly impact nutritive status of nearly two billion people around the world. The total world production of potato is estimated at $388.19 \mathrm{mt}$ in 2017 (FAO stat, 2019). India ranks second only to China, in terms of production, commanding a share of nearly $12.5 \%$ of the world's output. In 2017 , India produced 48.61 MT of potatoes (FAO stat, 2019).

Potato cultivation is limited to relatively cooler areas and seasons throughout the world due to photo and thermo sensitivity of the crop. It is grown only under such conditions where the temperature during the growing seasons is moderately cool. Temperatures above $30^{\circ} \mathrm{C}$ can have a range of negative 
effects on potato, including slowing tuber growth and initiation, less partitioning of starch to the tubers (Levy and Veilleux, 2007). The vegetative growth of the plant is best at a temperature of $24^{\circ} \mathrm{C}$ while tuber development is favoured at $18^{\circ} \mathrm{C}$. High temperature stress in potato lowers tuber yield both through reduction in the assimilate supply and reduced partitioning of assimilates to tubers (van Dam et al., 1996). The major effect of night temperature is on carbon partitioning among various plant parts, with temperatures above $18{ }^{\circ} \mathrm{C}$ favouring diversion of carbon towards the above ground parts at the cost of tubers, making the plants grow very tall and reducing harvest index (Wolf $e t$ al., 1990).

Potato is grown almost in all states of India. However, the major potato growing states are Himachal Pradesh, Punjab, Uttar Pradesh, Madhya Pradesh, Gujarat, Maharashtra, Karnataka, West Bengal, Bihar and Assam. In India about $80 \%$ of the potatoes are grown in north-western Indo- Gangetic plains during winter from October to February. About 10\% are grown in Himalayas and Nilgiri hills during summer and only $7 \%$ in the warmer plateau region during rainy season as well as winter (Pandey et al., 2007). Temperature being the limiting factor, the planting time varies from region to region. Temperature is the most limiting factor for cultivation of potato. The crop needs less than $24^{\circ} \mathrm{C}$ night temperature for proper tuberisation which limits its cultivation under tropical conditions. However, efforts are now being taken up to develop tropical potato varieties so that cultivation is possible in non traditional areas also, especially during winter season. The initiation of this tuber is triggered by short day lengths (photoperiods), and involves growth hormones. The colder the soil temperature, the more rapid the initiation of tubers and the greater the number of tubers formed. The optimum soil temperature for tuber initiation is 59 to $68^{\circ} \mathrm{F}\left(15\right.$ to $\left.20^{\circ} \mathrm{C}\right)$. (Anonymous, 2016).

Heat tolerance is by far the least important trait in adopted varieties, as just a few varieties present in India have a high tolerance to heat. However, in absolute terms high tolerance deserves future attention given the likely negative impact of warmer (extreme) temperatures on potato production (Willy, 2019). Hence, the present study aimed to evaluate the performance of heat tolerant clones of potato in tropical coastal region of India.

\section{Materials and Methods}

A field experiment was conducted at ICARCentral Tuber Crops Research Institute, Thiruvananthapuram, Kerala, during 2016-17 to evaluate heat tolerant genotypes of potato. Five heat tolerant advanced clones of promising crosses of potato developed at ICAR- Central Potato Research Institute, Regional Station, Modipuram, Meerut were evaluated/screened in tropical coastal soils along with two control variety, Kufri Surya and Kufri Lauvkar. The soil in the experimental area was deep, well drained, sandy clay loam, moderately acidic in reaction (Table 1). The minimum and maximum temperature prevailed during the growing season were also noted (Fig. 1). Five clones evaluated were HT/7-1329, HT/101554, HT/10-1559, HT/10-2002, HT/10-2816 along with released heat tolerant varieties, Kufri Surya and Kufri Lauvkar. Healthy, fifteen uniform sized tubers each were planted on ridges taken at $60 \mathrm{~cm}$ spacing giving 20 $\mathrm{cm}$ plant to plant distance. The crop was planted on 14th December 2016 and harvested on 20th March, 2017. The tubers were planted at a depth of 4 inches on ridges. Organic manure@15 tonnes and a fertilizer dose of $180-80-100 \mathrm{~kg}$ of $\mathrm{N}, \mathrm{P}_{2} \mathrm{O}_{5}$ and $\mathrm{K}_{2} \mathrm{O}$ per hectare were applied. Organic manure in 
the form of FYM @ $150 \mathrm{~g}$ and vermi compost @ 50g per plant were applied as basal dose. Nutrients in the form of urea, single super phosphate and muriate of potash were applied following standard recommendation. Half of the nitrogen and full phosphorus and potassium were applied as basal and the rest half of nitrogen, one month after establishment of the crop. The crop was irrigated daily by drip method after one week of planting near to field capacity.

Observations on sprouting of tubers and establishment of plants were recorded. The yield attributes such as number of tubers per plant, mean tuber yield and total tuber yield per plot were recorded at harvest. The tubers were graded into marketable ( $>20 \mathrm{~g}$ ) and non marketable $(<20 \mathrm{~g})$ and the yield per hectare was assessed. Morphological characters of tubers and the sensory evaluation of the chips fried from tubers was also assessed following standard procedures.

\section{Results and Discussion}

\section{Sprouting of tubers}

The crop started sprouting within a week after planting. Tubers of HT/7- 1329 germinated first taking only 7 days, followed by HT/ 101559 within 9 days. HT/ 10-1554 took 16 days for first sprouting. There is $100 \%$ sprouting for all the genotypes. $100 \%$ sprouting is achieved in HT/ 7-1329 within 18 days and in other clones, it ranges from 21-24 days. Number of days taken for sprouting in different clones is depicted in Fig. 2.

Normal sprouting time for potatoes planted in the soil ranges from 14 to 28 days, depending on the cultivar and soil and weather conditions. Early sprouting and establishment of the genotype HT/ 7-1329 showed its adaptability to the temperature range of 30$32^{\circ} \mathrm{C}$ maximum and $24-27{ }^{\circ} \mathrm{C}$ minimum temperature prevailed during the first three weeks after planting. The control Kufri Surya took 21 days for $100 \%$ establishment.

\section{Yield and yield attributes}

\section{Number of tubers per plant}

Tuber number ranged from 4.5 to 8 in different clones at the time of harvest. Maximum number is recorded in Kufri Surya (8.0) closely followed by HT/ 7-1329 (7.5). Minimum number of tubers is recorded by Kufri Lauvkar (4.6).

\section{Mean tuber yield per plant}

Mean tuber yield per plant ranged from $63 \mathrm{~g}$ in Kufri Lauvkar to $330 \mathrm{~g}$ in HT/ 7-1329. HT/10-2002 also recorded more yield (298 g) than the control (238 $\mathrm{g}$ ).

\section{Total tuber yield}

Maximum tuber yield per ha is noted in HT/ 7-1329 (27.5 tha ${ }^{-1}$ ) followed by HT/10-2002 $\left(24.8\right.$ tha $\left.^{-1}\right)$. Performance of Kufri Lauvkar is noted for poor yielder and recorded only 5.28 tha $^{-1}$ (Fig. 3).

\section{Marketable tuber yield}

Marketable tuber yield per ha was also maximum in HT/ 7-1329, followed by HT/102002. Small sized tubers, which are nonmarketable, was maximum in Kufri Lauvkar. Kufri Surya produced 14.7 tha $^{-1}$ of marketable tubers. In HT/ 7-1329 and HT/10$2816,24.2 \%$ of total tuber yield was culled out for non marketability. In Kufri Surya, $25.8 \%$ was found nonmarketable.

HT/7-1329 and HT/10-2002 recorded 38\% and $25 \%$ increase in tuber yield over the control variety Kufri Surya, indicating that these varieties perform well even at a night 
temperature of 24 to $28^{\circ} \mathrm{C}$ prevailed during the experiment period (Fig. 4).

The most widely used selection strategy to identify heat tolerance is to evaluate genotypes in a heat stress environment and to select those that have superior yields as compared to cultivars with better performance under these conditions (Wahid et al., 2007). Minimum temperature and maximum temperature varied from 23 to $27^{\circ} \mathrm{C}$ and $30-32$ ${ }^{\circ} \mathrm{C}$ during the crop period. Temperature being the first determinant which determines the suitability for cultivation of potato, minimum temperature below $18^{\circ} \mathrm{C}$ and maximum temperature below $30^{\circ} \mathrm{C}$ are ideal and these temperatures should prevail for sufficient number of days for the potato to tuberize and give economically viable yield (Minhas et al., 2011). When heat tolerance is introduced in any crop, an increase in the range of temperatures favourable for that crop occurs, consequently leading to increase in the thermally suitable period for crop growth. Of the genotypes tested, HT/7-1329 and HT/102002 were found promising under high temperature regimes of tropical situations.

Table.1 Physical and chemical properties of the soil (top $30 \mathrm{~cm}$ ) in the experimental area

\begin{tabular}{|c|c|c|c|c|c|c|c|c|c|c|c|}
\hline \multicolumn{6}{|c|}{ Physical } & \multicolumn{6}{|c|}{ Chemical } \\
\hline \multirow{2}{*}{$\begin{array}{l}\text { Sand } \\
(\%)\end{array}$} & \multirow{2}{*}{$\begin{array}{l}\text { Silt } \\
(\%)\end{array}$} & \multirow{2}{*}{$\begin{array}{l}\text { Clay } \\
(\%)\end{array}$} & \multirow{2}{*}{$\begin{array}{l}\text { FC } \\
(\%)\end{array}$} & \multirow{2}{*}{$\begin{array}{l}\text { WP } \\
(\%)\end{array}$} & \multirow{2}{*}{$\begin{array}{l}\text { BD } \\
(\mathrm{g} / \mathrm{cc})\end{array}$} & \multirow[t]{2}{*}{ pH } & \multirow{2}{*}{$\begin{array}{l}\text { EC } \\
(\mathrm{ds} / \mathrm{m})\end{array}$} & \multirow{2}{*}{$\begin{array}{r}\mathrm{OC} \\
(\%)\end{array}$} & \multicolumn{3}{|c|}{ Available Nutrients (kg/ha) } \\
\hline & & & & & & & & & $\mathrm{N}$ & $\mathrm{P}$ & $\mathrm{K}$ \\
\hline 69 & 7 & 24 & 14.5 & 5.8 & 1.30 & 5.2 & 0.08 & 0.59 & 365 & 55 & 160 \\
\hline
\end{tabular}

Table.2 Performance of heat tolerant genotypes of potato on yield attributes and yield

\begin{tabular}{|c|l|c|c|c|}
\hline SI No & \multicolumn{1}{|c|}{ Genotypes } & $\begin{array}{c}\text { No. of } \\
\text { tubers } \\
\text { /plant }\end{array}$ & $\begin{array}{c}\text { Marketable } \\
\text { tuber yield } \\
\text { (t/ha) }\end{array}$ & $\begin{array}{c}\text { Total tuber } \\
\text { yield(t/ha) }\end{array}$ \\
\hline $\mathbf{1}$ & HT/7-1329 & 8.0 & 20.83 & 27.5 \\
\hline $\mathbf{2}$ & HT/10-1554 & 7.5 & 4.44 & 11.94 \\
\hline $\mathbf{3}$ & HT/10-1559 & 5.2 & 3.47 & 16.25 \\
\hline $\mathbf{4}$ & HT/10-2002 & 5.1 & 18.19 & 24.86 \\
\hline $\mathbf{5}$ & HT/10-2816 & 5.1 & 13.89 & 18.33 \\
\hline $\mathbf{6}$ & K. Lauvkar & 5.0 & 1.94 & 5.28 \\
\hline $\mathbf{7}$ & K. Surya & 4.6 & 14.72 & 19.86 \\
\hline
\end{tabular}

Table.3 Morphological characteristic of fresh potato tubers

\begin{tabular}{|l|l|l|l|l|}
\hline Variety & Shape & Skin colour & Position of eyes & Flesh colour \\
\hline HT/7-1329 & Oval & White & Shallow eye & White \\
\hline HT/10-1554 & Round & Light Yellow & Shallow eye & Light Yellow \\
\hline HT/10-1559 & Oval & White & Shallow eye & Cream \\
\hline HT/10-2002 & Round & White & Shallow eye & Cream \\
\hline HT/10-2816 & Oval & White Cream & Shallow eye & Yellow \\
\hline Kufri Lauvkar & Round & White Cream & Shallow eye & Yellow \\
\hline Kufri Surya & Oval & Light Cream & Shallow eye & Yellow \\
\hline
\end{tabular}


Table.4 Sensory evaluation parameters of fried chips from tubers

\begin{tabular}{|l|l|l|l|l|l|}
\hline Variety & Texture & Appearance & Aroma & Test & Bitterness \\
\hline HT/7-1329 & Mealy & Good & Moderate & Good & Absent \\
\hline HT/10-1554 & Mealy & Very Good & Moderate & Very Good & Absent \\
\hline HT/10-1559 & Mealy & Excellent & Moderate & Very Good & Absent \\
\hline HT/10-2002 & Mealy & Very Good & Much & Very Good & Absent \\
\hline HT/10-2816 & Mealy & Very Good & Much & Very Good & Absent \\
\hline Kufri Lauvkar & Mealy & Fair & Much & Very Good & Absent \\
\hline Kufri Surya & Mealy & Good & Slight & Very Good & Absent \\
\hline
\end{tabular}

Fig.1 Minimum and maximum temperature (weekly) prevailed from planting to harvest

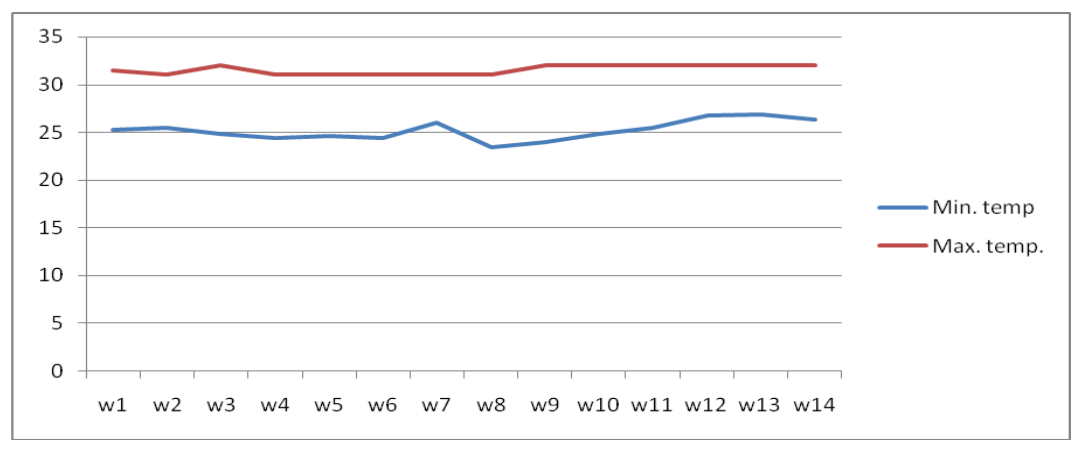

Fig.2 Percentage sprouting in different cultivars after planting

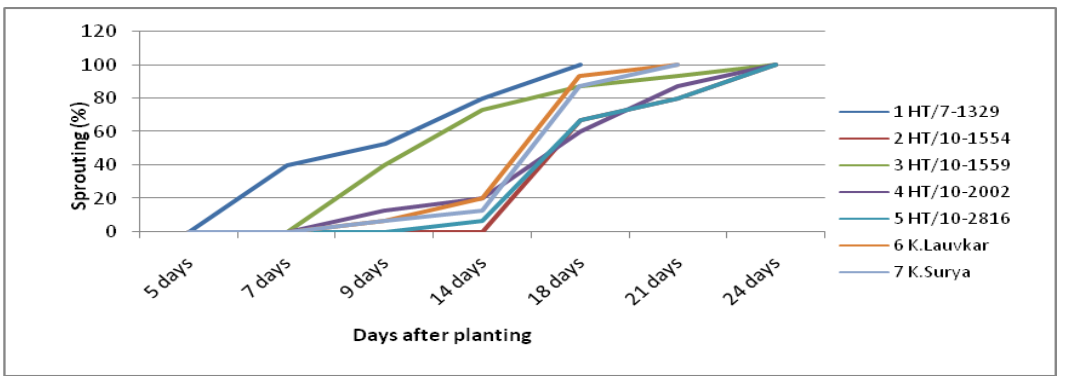

Fig.3 Total and Marketable tuber yield of different genotypes

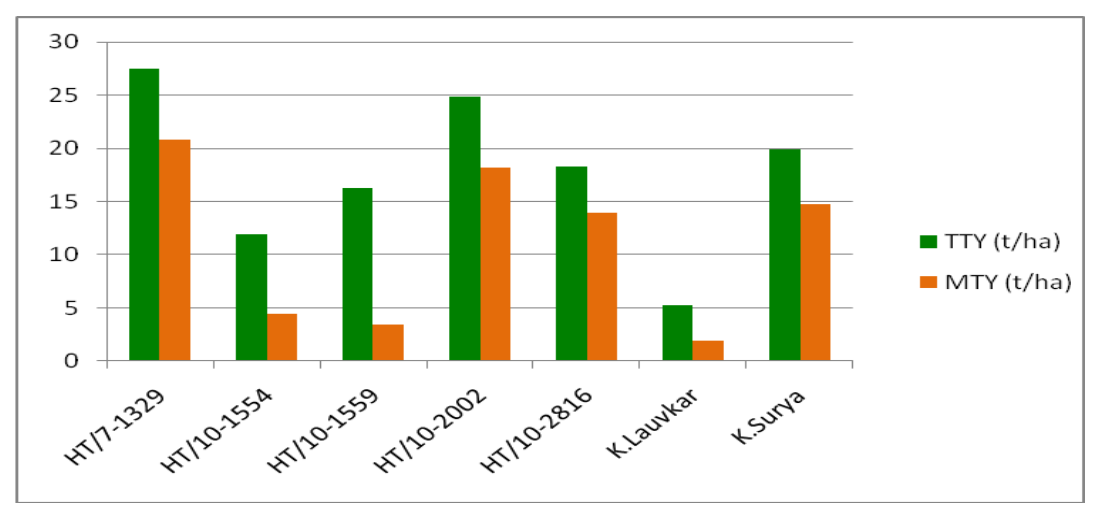


Fig.4 \% Increase/ Decrease in total/ marketable tuber yield of clones compared to Kufri Surya

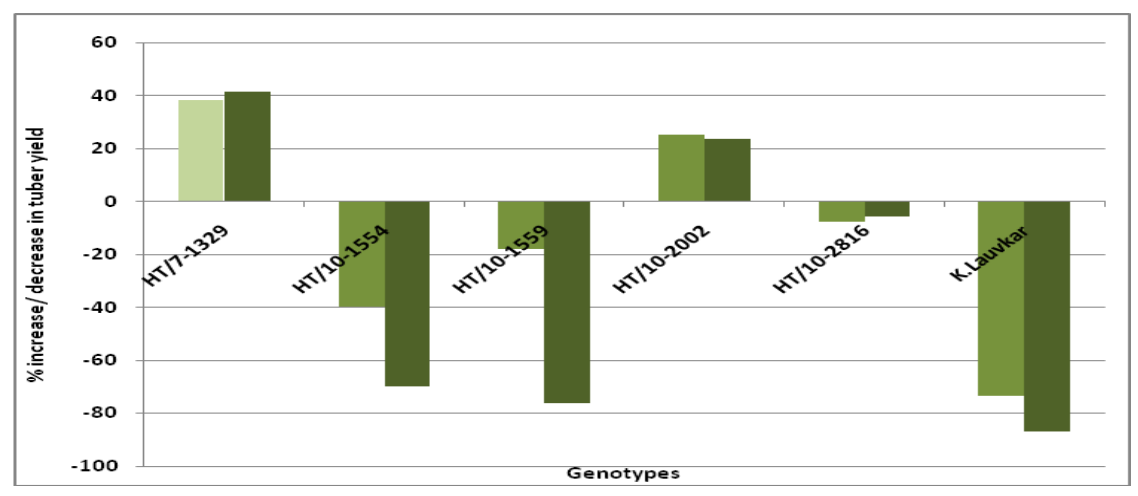

The minimum temperature varied from 23 to $25^{\circ} \mathrm{C}$ during the tuberising period of the crop. Kufri Surya, the first heat tolerant variety released from ICAR-CPRI, Shimla, even those is found suitable in situations where minimum temperature is $20^{\circ} \mathrm{C}$ and even $22^{\circ}$ C (Minhas et al., 2011). Present study indicates that the two genotypes HT/7-1329 and HT/10-2002 can tuberise even at a minimum temperature regime of $23-25^{\circ} \mathrm{C}$ and give satisfactory tuber yield. The results are in agreement with other researchers who investigated that tuber yield varies significantly with variety and location (Gebreselassie et al., 2016, Preetham, 2018)

\section{Morphological and sensory evaluation of tubers}

Morphological characteristic of fresh potato tubers and the sensory attributes grown under tropical conditions recorded in Table 3 and 4.

The taste and crispiness of fried chips was also good for HT/10-2002 followed by HT/71329, compared to Kufri Surya. Selected genotypes had acceptable texture and taste without bitterness due to alkaloids in organoleptic test conducted after harvest. The influence of location and cultivars on quality of potato tubers have been reported by researchers (Uppal and Paul, 2001; Kumar et al., 2003).
In conclusion with growth in the world population and rising temperatures, more heat tolerant cultivars are going to be needed in near future. Two clones i.e., HT/7-1329 and HT/10-2002 were found suitable to cultivate in tropical regions during rabi season based on the studies conducted. It has also been observed that by selecting suitable tuber crop as inter crop would further help to reduce effect of high temperatures in potato during crop growth. Effective management of bacterial wilt and sucking pests would be helpful to expand this crop in the tropical coastal regions. This study reveals that potato cultivation would become feasible in many locations in Kerala with the deployment of the heat tolerant varieties similar to or better than Kufri Surya. However, agro techniques are to standardised for these varieties including deep planting in the cool moist soil layer, frequent irrigations to lower the soil temperature, proper mulching etc for realising full potential of a variety.

\section{Acknowledgement}

The authors acknowledge the support given by Dr. S.K. Chakrabarti, Director, ICARCPRI, Shimla, for undertaking the study.

\section{References}

Anonymous 2016. www.krishisewa.com van Dam, J., Kooman, P.L. and Struik, P.C. 
1996. Effect of temperature and photoperiod on early growth and final number of tubers in potato, Potato Res. 39: 51-62. FAO stat. 2019. www. FAO stat.org.

Kumar, D., Ezekiel, R. and Khurana S.M.P. 2003. Effect of location, season and cultivar on the processing quality of potatoes. J. Indian Potato Assoc., 30, 247-251.

Levy, David and Veilleux, R. E. 2007. Adaptation of Potato to High Temperatures and Salinity - A Review, American Journal of Potato Research, 84 (6): 487-506.

Minhas J.S., Rawat, S., Govindakrishnan P.M. and Kumar D. 2011. Possibilities of enhancing potato production in nontraditional areas, Potato J. 38 (1): 14-17. Pandey, N.K., Pandit, A., Chandran, K.P. and Pandey, S.K. 2007. Potato statistics: India and world, CPRI Technical Bulletin No. 81, Central Potato Research Institute, Shimla. Pp. 121.

Preetham, Ashwini and Pavan 2018.
Evaluation of Potato Varieties for their Suitability under Northern Telangana Agro Climatic Conditions, Int.J.Curr.Microbiol.App.Sci. 7(4): 400406.

Uppal, D.S. and Khurana, S.M.P. 2001. Chipping performance of potato varieties grown at different locations. $J$. Indian Potato Assoc., 28, 233-236.

Wahid, A., Gelani, S., Ashraf, M. and Foolad, M.R. 2007. Heat tolerance in plants: An overview, Environmental and Experimental Botany. 6, 199-223.

Willy Pradela, Marcel Gattob, Guy Hareaua, S.K. Pandey, Vinay Bhardwayd 2019. Adoption of potato varieties and their role for climate change adaptation in India, Climate Risk Management. 23, $114-123$.

Wolf, S., A. Marani and J. Rudich 1990. Effect of temperature and photoperiod on assimilate partitioning in potato plants, Ann. Bot. 66, 513-20.

\section{How to cite this article:}

Sunitha, S., VK. Gupta, Shirly Raichal Anil and Suresh Kumar, J. 2020. Performance of Heat Tolerant Clones of Potato in Tropical Coastal Region of India. Int.J.Curr.Microbiol.App.Sci. 9(08): 2961-2967. doi: https://doi.org/10.20546/ijcmas.2020.908.332 